\title{
(Ending) Civil War in the Classroom: A Peacebuilding Simulation
}

Rex Brynen, McGill University

ABSTRACT There often exists a problematic gap between more theoretical works on warto-peace transitions, and the practical challenges that peacebuilding operations face in the field. This article describes the use of classroom simulation to highlight the complexity of contemporary multilateral peace operations. It describes the content and mechanics of the simulation, the issues that can arise in its operation, and strategies for most effectively integrating such a simulation into overall course objectives.

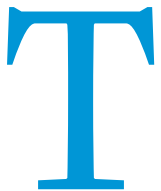

he post-cold war era has seen substantial growth in the number and complexity of multilateral peace operations. As of June 2009, some 115,321 personnel were deployed in 17 United Nations peacekeeping missions worldwide (United Nations Department of Peacekeeping Operations 2009), in addition to the tens of thousands of non-UN international forces present in countries such as Bosnia (EU/EUFOR), Kosovo (NATO/KFOR), and Somalia (African Union/AMISOM). Moreover, with the 9/11 terrorist attacks came U.S. intervention in Afghanistan and Iraq, and massive postintervention counterinsurgency and stabilization operations in those countries too. Although the U.S. continues to draw down the more than 100,00o American troops still in Iraq, the approximately 90,00o U.S. and NATO troops in Afghanistan are set to "surge" to some 120,000 or more in 2010 (Department of Defense 2009). Although definitions vary, well in excess of $\$ 40$ billion in official development assistance flows to fragile and conflictaffected countries each year (2007 data, calculated from Organization for Economic Cooperation and Development 2009). For diplomats, militaries, aid agencies, non-governmental organizations, and the UN system alike, conflict prevention, peacebuilding, and post-conflict reconstruction have become increasingly important parts of their activities.

With all this, there is a corresponding need to teach about peace and stabilization operations in the classroom. Yet despite the proliferation of scholarly and policy materials on peacebuilding, there is often a problematic gap between the theoretical focus of readings and the practical challenges of undertaking such operations in an environment characterized by voluminous and yet limited and often conflicting information, competing national priorities, differing professional and institutional perspectives, bureaucratic politics, and coordination challenges-not to mention the political ambitions and machinations of local actors.

A classroom simulation offers one way of addressing this gap. Simulations can help to illustrate and explore complex policy processes in the classroom, especially those regarding negotiations

Rex Brynen is professor of political science at McGill University. His research interests include Middle East politics, international development, international security, and peace building. He can be reached at rex.brynen@mcgill.ca. and international relations (Preston 2000; Lantis 2000; Hobbs and Moreno 2000; McIntyre and Callahan 2000; Starkey and Blake 2001). However, while peace operations are frequently wargamed in the military, it is only recently that simulations have been used in the training of UN and other personnel, ${ }^{1}$ and there are even fewer efforts to simulate civil war termination in the university classroom.

In order to address this gap, this peacebuilding simulation accompanies undergraduate (POLI 450) and graduate (POLI 650) courses on peacebuilding at McGill University. The first simulation, conducted in 1998, was held over five days among the two dozen members of a mixed-graduate/upper-level undergraduate seminar group. It has grown substantially in size and scope since then, however, and now typically consists of around 10 MA and Ph.D. students, 100 upper-level undergraduates, and another 10 to 20 other undergraduates in supporting roles, engaged in intensive role playing for a full week. Background materials and simulation rules are available online at a dedicated Web site, http://www.brynania.net.

As suggested above, the key purpose of the simulation is to highlight the complex and interrelated dynamics of peace operations in a way that course readings are unable to do so. Of particular importance in this regard is the simulation's role in demonstrating why-despite all of the political science literature, lessons-learned reviews, and agency catalogues of best practices-such operations often generate both suboptimal processes and disappointing outcomes, for reasons that are frequently embedded in the pathologies of organizations (Barnett and Finnemore 1999) and politics of peacebuilding. Although not a primary goal of the simulation, the exercise also contributes to a number of practical student skills, including public speaking, negotiation, team and information management, and effective and professional written communications.

\section{SIMULATION SETTING}

The simulation is set in a fictitious country and continent, but located in the real world. There are several reasons for doing this. First, the conflict setting can be designed to illustrate various themes from the course all within a single country. Students are 
also less likely to feel constrained by historical precedent. At the same time, the real-world contextual setting offers reasonable constraints on the capacities of external actors and agencies. Another major reason for using a fictitious country is one of political sensitivity: passions might become inflamed in a simulation where some members of the class might have ethnic or family ties to the conflict in question.

The focus of the simulation is the war-torn country of "Brynania," where a long-standing civil war pits an authoritarian military regime (dominated by the majority Brn ethnic group) against a separatist Zaharian insurgency in the south (led by the Popular Front for the Liberation of Zaharia, and the smaller, more radical Zaharian People's Front). The Zaharians have blockaded the country's major port of Mcgilldishu. The northern Brn warlords of the Free People's Army, who defy government authority and control the northern diamond-producing region of the country, pose a further challenge. To the west, there is also some unrest among the small Icasian ethnic minority. The civil war in Brynania thus most closely resembles civil wars in Central or West Africa, with a weak central government, ethnic tensions, and a multiplicity of armed groups, warlordism, and lootable resources.

Brynania is one of six countries that occupy the continent of Cyberia. To the west, it is bordered by Icasia, a large, corruptionplagued almost-failed state (based loosely on Mobutu's Zaire). To the east it is bordered by powerful Ruritania, an authoritarian regime that has offered military support to the Brynanian government (based loosely on Syria). The remaining countries of the region comprise Concordia (a small and stable pro-Western democracy), Uqamistan (a poor, radical regime), and Udem (an impoverished country hosting a large French military base).

The initial military and political situation is designed to be a hurting stalemate (Zartman 1995, 18), with no one actor able to secure outright victory on the battlefield. At the start of the simulation, an informal ceasefire is in effect, which the international community hopes can be transformed into a formal peace agreement.

The simulation lasts seven days of real time, corresponding to seven months of simulation time. Each day thus represents a month in Brynania, and by convention each hour of real time corresponds to one day. ${ }^{2}$ This time period allows the simulation to cover-should the ceasefire hold-such elements as humanitarian assistance operations, peace negotiations, preliminary deployment of any peacekeepers, formation of a transitional government, refugee repatriation, and the shift to longer-term development programming.

A broad variety of actors are represented in the simulation. In addition to the six countries of Cyberia, all five permanent members of the UN Security Council (U.S., Russia, China, UK, and France) are represented, as are Canada, Norway, a few additional European countries (usually those holding the European Union presidency that year), and a few major developing countries (usually major UN troop contributors or current members of the Security Council). Each of these countries is assigned two to five students, typically representing the foreign and defense ministries, the national aid agency, and other relevant actors (such as the UN ambassador or U.S. National Security Council). ${ }^{3}$ In addition to a special representative of the secretary general (SRSG) for the conflict in Brynania, the UN system is also represented by teams for the Department of Political Affairs, the Department of Peacekeeping Operations, the Office for the Coordination of
Humanitarian Affairs (OCHA), United Nations High Commissioner for Refugees (UNHCR), United Nations Children's Fund (UNICEF), United Nations Development Programme (UNDP), World Food Programme (WFP), and the Office of the UN High Commissioner for Human Rights. The World Bank is also represented. Non-governmental organizations typically include the International Committee of the Red Cross, Médecins Sans Frontières, CARE, Oxfam, and Amnesty International.

Finally, a host of local actors are represented. In addition to the government of Brynania and the various rebel factions, these include the local media (local pro-government and independent radio stations, modeled on Rwanda's notorious Radio Télévision Libre des Mille Collines and Serbia's Radio B92 respectively), the regional Cyberian Times, a local human rights group, a progovernment paramilitary movement, a pro-Zaharian aid group, and a national trade union.

\section{SIMULATION MECHANICS}

The simulation design incorporates elements of both role playing and frei kriegspiel. ${ }^{4}$ In keeping with the latter, there are only few written rules, with the outcome most actions being adjudicated by "Control" (the course instructor). The most detailed rules exist for resource allocation for humanitarian and development activities. These are intended to force aid providers to carefully weigh what sorts of programming they will support where, as well as the opportunity costs of any sort of action. In addition, the government of Brynania is forced to make some "guns versus butter" trade-offs in its own budgeting, and all combatants must consider resource mobilization as a necessary part of their military and political strategy. Control uses a spreadsheet-based algorithm (factoring in war damage, transportation access, population displacement, aid levels, and program quality) to determine how socioeconomic conditions might change in different areas of the country from (simulated) month to month. This, however, could be dispensed with in a smaller simulation.

This open simulation mechanic allows for considerable nuance and complexity in the simulation, with policymakers only limited by Control's decisions as to what is reasonable and realistic. An alternative approach, in a shorter simulation with fewer actors, would be to limit the policy choices of each actor to a fixed menu of choices, each with certain opportunity costs attached. This is the approach taken by the World Bank, for example, in its Carana training simulation (although participants can seek to modify the choices presented to them). Such a method provides greater transferability of the simulation from instructor to instructor, although with greater initial investment in design and play testing.

Early in the term, students are asked to submit a ranked list of their role preferences. Every effort is made to accommodate these preferences, on a first-come, first-served basis. The most influential roles are typically assigned to graduate and honors students, although this is not always the case. Ideally, the key military roles are assigned to students with some military background or knowledge, since experience has shown that students without this background may otherwise have difficulty with the assignment.

Approximately one week prior to the simulation, students are given a short briefing document outlining their actors, their general objectives, and the resources available for use in Brynania (aid budget and any military forces available for peacekeeping operations). They are encouraged to consult with the instructor 
should they require any further information or guidance. In addition, extensive background material on the conflict and its actors can be found on the simulation Web site. This includes mock CIA World Factbook entries for each country in Cyberia, fictitious UNDP statistical data and OCHA reports on humanitarian conditions, mock newspaper and magazine articles, and even video reports and cultural items. The latter-most of them contributed by students over the years-even include a number of political songs set in the simulation universe, written and recorded by local bands. ${ }^{5}$ During the simulation, many students also often prepare their own Web pages to highlight the policies and positions of their respective actors.

During the simulation itself, students play their roles through e-mail correspondence, face-to-face meetings, instant-messenger software, Voice over Internet Protocol (VoIP), and telephone conversations. ${ }^{6}$ Two e-mail lists (listservs) are used to broadcast simulation news and developments: one for routine items, and the other for official news reports (generated by Control or the Cyberian Times) and flash alerts. A simulated online New York Times is also published for the start of each day, summarizing the previous day's events and any overnight developments. Students can also request additional information from their staff (Control) at any time. ${ }^{7}$ Humanitarian actors typically receive an update at the start of the day on conditions in their areas of operations. Military actors are provided with an updated map of military deployments as necessary.

An e-mail curfew rule limits participation to 12 hours per day (9 a.m. until 9 p.m.). There is no expectation that students (as with their real-world counterparts) are available to give the simulation their full and undivided attention. Typically, however, many in the class do indeed put this many hours, or more, into the simulation.

All e-mails, together with instant-messenger transcripts and minutes from face-to-face meetings, must be copied to Control, so that events can be fully monitored. This typically involves the course instructor reading more than 10,0oo e-mails over the course of a week. ${ }^{8}$ Experience has shown that the only way to do this is to cancel all teaching during the simulation week, and spend it glued to the computer. This volume of communications, however, is a function of class size, and is much less burdensome with smaller groups. It is also possible to use teaching assistants to manage part of the simulation, such as updating actors on military conditions or socioeconomic conditions.

How students engage in the simulation can be very different, depending both on their roles and how developments in Brynania unfold.

Diplomatic actors typically find themselves focused on securing a peace agreement, establishing the foundations for cooperative multilateral engagement (spiced, of course, with some national rivalry), and developing a communications strategy to put their policies in the best public light. Although the appointment of an SRSG often means that the UN acts as the primary mediator, at times the U.S., EU, the "Organization of Cyberian Nations," and even individual states have assumed this role.

Aid actors must mobilize and allocate assistance, mindful of both humanitarian need and the political complexity of operating in a highly politicized and conflictual environment. For aid donors, resources must be provided in a way that advances both national goals and (usually) the broader peace process. NGOs must not only design programs (with the quality of these determining their relative effectiveness), but they must also secure financial support from donor countries and the general public. The latter is represented by a dozen or so "public opinion" players drawn from another class, who follow the simulation as it unfolds, receive advertising material from NGOs, and determine each day where to donate their resources.

Military actors have very different roles from simulation to simulation. In some, the ceasefire soon breaks down, resulting in a heavy workload for the combatants and little for outside militaries to do beside the occasional rescue of foreign nationals or evacuation of embassy staff. Other times, UN, OCN, or other multilateral peace operations are established, in which case forces must be committed, rules of engagement drawn up, and deployments and operational orders decided upon. Typically-and much like the real world-this is a long and time-consuming process, with missions often suffering a significant gap between their formal mandate and the scarce peacekeeping resources committed to them.

Civil society actors, such as the media, trade union, and human rights groups, have less clearly defined roles, and here perhaps the most variation can be seen depending on how students approach the simulation. Past simulations have included human rights campaigns to release an imprisoned poet ("Zahra al-Zahra"), a general strike, and lively media commentary (including podcasts and video).

A conscious effort is made by Control not to steer the simulation in certain directions, but rather to let matters unfold as a result of students' actions. ${ }^{9}$ Indeed, a core aspect of the exercise is to allow students to suffer the consequences of, and hence learn from, their mistakes. At times, however, participants have to be prevented from taking actions that violate the rules or are grossly unrealistic.

There are several ways in which these challenge can be dealt with by Control: a helpful memo from "junior staff" to decision makers pointing out the possible consequences of their illconceived action; a very public traffic accident (usually involving the colorful local "Simsim birds" native to Cyberia) that signals a rule violation or even keeps someone suspended from participation for a few hours; or more drastic intervention. Fortunately, major deus ex machina interventions have been extremely rare, and most participants have kept within the bounds of both the rules and their role assignments.

A related problem is the tendency of some players to metagame the simulation-seeking to manipulate the game rules or mechanics so as to "win" rather than "simulate." This particularly manifests itself in the closing days, when risk aversion declines and frustration mounts. Students are warned against this, and urged to participate as if the simulation continued indefinitely.

In both designing and running the simulation, several issues have arisen that underscore the sensitivities of using a week long "game" to highlight the life and death challenges of peace operations:

- Humor. While the core of the simulation of the simulation is designed to be as realistic as possible, in nonetheless contains a number of humorous items, and inside jokes often abound during the course of the week. This might seem rather out of place, given that thousands of simulated lives are at stake in war, famine, and forced displacement in Cyberia. At the same time, it helps to alleviate the burden of the 12- to 
16-hour days that many students put into the simulation for a full week during one of the busiest times of the term. In this respect, it very much echoes the use of humor as a coping mechanism in actual field operations (Williams 2001), a point made in class lectures. Students have not found this inappropriate, and have typically welcomed it.

- Ethnicity and Religion. While the simulation features issues of ethnic identity and conflict, there is no similar treatment of religion. Participants, while easily able to slip into fictitious ethnicities, would find it more difficult (and less realistic) to assume fabricated religions. Conversely, using real religious identities would likely be too sensitive, especially given some of the propaganda and violence used during the simulation by the combatants.

- Realistic Violence and Traumatic Stress. The simulation could pose problems for students who have lived in war-torn countries, lost loved ones in civil conflicts, or suffered themselves from physical or sexual violence and post-traumatic stress. This issue is dealt with in two ways. First, the instructor makes explicit mention of these issues before the simulation, and urges anyone who might be affected to consult closely before taking part. Second, an effort is made to limit the use of graphic images and highly descriptive text during the simulation. This has meant, for example, that simulated Human Rights Watch reports have had to be rendered less detailed than might be the case in real life. No student has ever chosen not to participate in the simulation for personal stress reasons, and no student has ever expressed a subsequent wish that they had not participated.

\section{MAXIMIZING THE LEARNING POTENTIAL OF THE SIMULATION}

The simulation does not exist, obviously, for its own sake, but rather to inform and educate its participants. This consideration, consequently, shapes the way the exercise is integrated into the broader POLI 450 and POLI 650 courses.

The simulation exercise is held towards the end of the term, after the class has had time to cover the main components of war-to-peace transitions in class in lectures, readings, and case studies. These include modules on such topics as civil war, negotiation/mediation, coordination, humanitarian assistance, refugees, DDR (demobilization, disarmament, and reintegration of former combatants), demining, peacekeeping, war crimes and human rights, governance and rule of law, economic reconstruction, and gender and peacebuilding. In addition, a one-hour in-class exercise is conducted on conflict-sensitive development planning. This relatively late timing of the simulation does have the disadvantage that it falls during a busy time of year, when students have term papers due for other classes. They are, however, warned about this from the very first day of class. In addition, the POLI 450 term paper itself is due before the simulation takes place.

Relatively little grade weight $(10 \%)$ is assigned to simulation participation itself. The vast majority of students are very enthusiastic, and lack of participation has not been a problem. ${ }^{10}$ Were this not the case, the participation grade could be increased somewhat to encourage greater involvement. However, it would be unwise to increase it too much: the direction of the simulation varies each year, and it is thus difficult to design roles with equal opportunities for engagement. It would also be a challenge mon- itoring some forms of participation, such as face-to-face meetings. The participation grade is based on both the extent of participation (with e-mails serving as a proxy measure) and the quality of role playing (based on the instructor's impression).

Following the simulation, students are required to write a short "lessons learned" paper each, worth 10\% (POLI 450) or 15\% (POLI 650) of their grades. These can be written either from the perspective of their simulation actors ("what I did well, and would have done differently") or as a student ("what I learned as a student of peacebuilding").

Once these assignments have been submitted, the instructor provides a detailed debrief for the class, highlighting key aspects of the simulation, as well as providing a comparison with past years. Typically the simulation provides myriad examples of the intensely political character of humanitarian and reconstruction efforts in war-torn areas, the complexities of multilateral peace operations, ethnic conflict and conflict-resolution, resourcemandate gaps, the challenges of donor coordination, bureaucratic politics (especially in the larger teams), the importance of information flows, and the "fog of war" and peace. Because all written communications and meeting minutes have been copied to Control, the class debriefing can be used to process trace why and how particular decisions, policies, and actions unfolded as they did, and how they were viewed and responded to by other actors.

How effective is all of this in providing students with insights into the dynamics of peacebuilding, and how does it compare to conventional readings and lectures? It is not, of course, a substitute for more traditional learning methods: the simulation represents only one week out of the term, building on the information and analysis imparted in the previous 12 weeks. Both anecdotally and in end-of-term evaluations, students have generally praised the simulation for having made a major contribution to their understanding of the politics and processes of peace operations. This has been especially strongly reiterated by those students who have gone on, after graduation, to careers in aid, diplomacy, and the military.

There are other benefits too. Student evaluations often highlight the perceived contribution of the simulation to negotiation and other interpersonal skills, as well as to formal and professional communications. Finally, civil war in Brynania is often a bonding experience for the class, with participants remaining in contact for years after, and several Facebook groups devoted to the "conflict."

\section{ADAPTING THE SIMULATION}

The Brynania simulation involves an extensive investment of time, both in terms of the various background materials developed over the years, as well as the time it takes to monitor the role playing of a large class for a week. However, the basic model of a moderated simulation using Web-based informational materials and internet communication can be readily adapted to smaller groups and other settings.

As evidence of this, a modified version of the model was used by the Royal Institute of International Affairs (Chatham House) in June 2008 to simulate Israeli-Palestinian refugee negotiation. In this case, materials and simulation "news" were published on a (free) Wordpress blog account, and (equally free) Gmail accounts were used for e-mail. The participants, rather than being undergraduate and graduate students, were almost three dozen current and former diplomats, negotiators, journalists, and issue experts 
(Chatham House 2008). The simulation was considered such a success that the UK Foreign Office requested and financed a follow-up meeting on the issues raised by the simulation a few months later.

Moreover, the task of implementing this type of simulation may soon become much easier, thanks to the Open Simulation Platform initiative current being supported by the United States Institute of Peace. When finished, this software will allow course instructors to either import or adapt a simulation prepared elsewhere, or to author their own scenarios through a user-friendly Web interface. The software will facilitate the preparation and distribution of (public and private) player briefings, and allow the instructor to control various simulation parameters such as duration, tasks, and communications linkages. Players will be able to interact and collaborate within the simulation via embedded e-mail and instant messaging (Gunn 2008).

$$
* * *
$$

The civil war in Brynania will continue again next year, with another group of students challenged to build (simulated) peace in that unfortunate country. In doing so, their experience will help to make real, in a way that lectures cannot, the myriad complexities of contemporary multilateral peace operations.

\section{NOTES}

I would like to thank the anonymous reviewers of PS: Political Science and Politics for their very useful comments on an earlier draft of this article. Further information on peacebuilding simulations can be found at the PaxSims blog at http://paxsims. wordpress.com

1. Most notably, there has been use of the simulated country of "Carana" for the training of UN, World Bank, and other personnel. For the World Bank simulation, see PaxSims (2009)

2. The result of this, of course, is that the twenty-fifth through thirty-first days of each month simply vanish-which has no practical effect on the simulation.

3. Initially, the Central Intelligence Agency was also represented. However, it soon became evident that students had a far too "Hollywood" view of the intelligence community, and little knowledge of its analytical functions. Consequently, the role was dropped. This may point to a broader problem in undergraduate education, insofar as the role of intelligence communities in national decision making is poorly understood.

4. First developed by the Prussian and German General Staffs in the nineteenth century, frei kriegspiel is a system of war gaming in which outcomes are decided by experienced umpires rather than by detailed systems of written rules. The system continues to be used frequently in military war games, especially staff exercises.

5. See the "Information Centre" and "Media Section" areas of http://www. brynania.net.

6. Students are assigned dedicated e-mail addresses within the university e-mail system for their roles. This speeds up delivery times, and reduces the risk of disruption due to problems with external mail servers such as Hotmail, Yahoo, and Gmail.

7. Whether or not such information is provided depends on whether it would be available to their real-world counterparts. In practice it also depends on the pace of the simulation at the time, and whether Control has the expertise to answer the question. It pays, therefore, to anticipate questions and have answers ready that can simply be pasted into an e-mail response.

8. During the 2008 version of the simulation, 12,015 e-mails were read or sent by Control, and the university e-mail servers had to handle an estimated 192,000 e-mail deliveries over the seven days (since most e-mails have multiple destinations).

9. Of the 10 times the simulation has been conducted, there has been a political agreement on transition to a post-conflict phase four times; a partial or tenuous agreement, with periodic fighting, three times; continued full-scale civil war twice; and widespread ethnic cleansing (followed by international intervention) once. UN peacekeeping operations have been deployed in six of the ten simulations, with varying degrees of success. On one occasion, ill considered policy initiatives managed to tip neighboring Icasia into civil strife too.

10. At McGill, the simulation benefits from a combination of limited course places and a first-come, first-served online registration system. Since the course fills up extremely quickly, typically only the most eager students-most of them in political science or international development studies-secure places.

\section{REFERENCES}

Barnett, Michael, and Martha Finnemore. 1999. "The Politics, Power, and Pathologies of International Organizations.” International Organization 53 (4): 699-732.

Chatham House. 2008. "The Regional Dimension of the Palestinian Refugee Issue: Simulation Exercise Report." June 23-25. http://www.chathamhouse.org.uk/ files/12092_prsimulationo6o8.pdf.

Department of Defense. 2009. "Special Report: Afghanistan Buildup.” December 5. http://www.defense.gov/home/features/2009/1209_afghanbuildup/.

Gunn, Allen. 2008. “The Open Simulation Platform.” White paper. http:// www.opensimplatform.org/wp-content/uploads/2008/o9/ opensimplatformwhitepaper.pdf

Hobbs, Hedi, and Dario Moreno. 20oo. "Bureaucratic Bargaining Revisited: A US Foreign Policy Simulation." In The New International Studies Classroom: Active Teaching, Active Learning, ed. Jeffrey Lantis, Lynn Kuzma, and John Boehrer. Boulder: Lynne Rienner Publishers.

Lantis, Jeffrey S. 200o. "Securing Tomorrow: The United Nations Security Counci Restructuring Summit.” In The New International Studies Classroom: Active Teaching, Active Learning, ed. Jeffrey Lantis, Lynn Kuzma, and John Boehrer. Boulder: Lynne Rienner Publishers.

McIntyre, Michael, and Patrick Callahan. 200o. "Constructing Effective Systems: Simulating the Paris Peace Conference." In The New International Studies Classroom: Active Teaching, Active Learning, ed. Jeffrey Lantis, Lynn Kuzma, and John Boehrer. Boulder: Lynne Rienner Publishers.

Organization for Economic Cooperation and Development. 2009. "Statistical Annex, 2009 Development Cooperation Report.” http://www.oecd.org/dac/ stats/dac/dcrannex.

PaxSims. 2009. "Carana." http://paxsims.wordpress.com/2009/01/27/carana/.

Preston, Thomas. 200o. "Securing Tomorrow: A Simulation of the National Security Process." In The New International Studies Classroom: Active Teaching, Active Learning, ed. Jeffrey Lantis, Lynn Kuzma, and John Boehrer. Boulder: Lynne Rienner Publishers.

Starkey, Brigid, and Elizabeth Blake. 2001. "Simulation in International Relations Education." Simulation and Gaming 32 (December): 537-551.

United Nations Department of Peacekeeping Operations. 2009. "Background Note.” June 3o. http://www.un.org/Depts/dpko/dpko/bnote.htm.

Williams, Sue. 2001. "The Usefulness of Humor." In Peacebuilding: A Field Guide, ed. Luc Reychler and Thania Paffenholz. Boulder: Lynne Rienner Publishers.

Zartman, I. William. 1995. "Dynamics and Constraints in Negotiations in Internal Conflicts." In Elusive Peace: Negotiating an End to Civil Wars, ed. I. William Zartman. Washington, D.C.: The Brookings Institution. 